\title{
QNLANRI
}

Jurnal Borneo Administrator

Volume 17 (3) 2021: 365-378

P-ISSN: $1858-0300$, E-ISSN: $2407-6767$

DOI: $10.24258 / j b a . ~ j b a . v 17 i 3.872$

Accredited by Kemenristek/BRIN No. 148/M/KPT/2020

ARTICLE

\section{Implementation of Data Collection Policy and Tax Information on Directorate General of Taxes}

\author{
Redhy Matabean ${ }^{*}$ and Vishnu Juwono² \\ ${ }^{1}$ Directorate General of Tax, Jl. Gatot Subroto Kav. 40-42 South Jakarta, Indonesia \\ ${ }^{2}$ Faculty of Administrative Science, Universitas Indonesia, Depok, Indonesia.
}

How to cite: Matabean, Redhy and Juwono, Vishnu. (2021). Implementation of Data Collection Policy and Tax Information on Directorate General of Taxes. Jurnal Borneo Administrator, 17(3), 365-380. Doi: https://doi.org/10.24258/jba.v17i3.878

\author{
Article History \\ Received: 25 March 2021 \\ Accepted: 3 December \\ 2021 \\ Keywords: \\ Data and Information \\ Collection, \\ Tax, \\ Policy Implementation
}

\begin{abstract}
The Directorate General of Taxation has the authority to collect data and information related to taxation from agencies, institutions, associations, and other parties (ILAP) through Government Regulation No. 31 of 2012. Data and information collected from the ILAP, including transaction, identity, licensing, and non-transactional data, are used to build tax databases and explore potential taxation. This study aims to analyze the implementation of data and information collected in the context of taxation and investigate the factors that support and inhibit the implementation by using the variable implementation of the hybrid policy model. This work is qualitative research with a post-positivist approach. Data collection was done by conducting in-depth interviews and literature reviews. Data analysis was carried out through data reduction, presentation, conclusions, and verification. The study showed that the implementation of data collection and information related to taxation has helped the Directorate General of Taxation build a tax database and taxpayer profile. However, there are still obstacles, such as the unavailability of an information system to monitor data use and barriers in incomplete data received. The inhibiting factors affecting implementation are the non-target setting of policy objectives and standards, lack of resources, and inadequate communication and coordination. The factors that support the implementation of this policy are the high motivation of policy implementers, the active role of policy implementers, and the adaptability of implementers.
\end{abstract}

\section{A. INTRODUCTION}

The implementation of the self-assessment system in Indonesia gives authority to taxpayers to calculate their tax obligations. The consequence of the system is the supervision of the tax authorities to test taxpayers' compliance whether the reporting of notification letters (in the future referred to as SPT) appropriate with the provisions of taxation. However, massive tax avoidance efforts are challenges for the Directorate General of Taxes (DJP), as Indonesia's tax authority, to supervise taxpayers. One indicator is the entry of Indonesia as a country with a high level of tax avoidance. According to a tax avoidance report by Ernesto Crivelli, an Investigator of the IMF and the International Center for Taxation and Development (ICTD), Indonesia ranks 11 th out of 30 countries with the highest tax evasion rates. The value of taxes not paid by corporations in Indonesia to the country is estimated at USD 6.48 billion

\footnotetext{
* Corresponding Author

Email : redhy.matabean@gmail.com
} 
(Simanjuntak, 2017). According to Pratomo (2018:167), the Indonesian tax authorities' inability to detect tax non-compliance is due to limited information and ineffective information exchange mechanisms between authorities.

To realize effective supervision, Nugroho (2018) requires several conditions. First is the mapping of the taxpayer's economic profile and compliance profile. Second is the transparency of data and information for tax purposes. The third is the availability of a single identity as a link to all data and information related to taxation. Tax authorities should also have the ability to know the economic profile and tax profile of the taxpayer so that the Tax Gap can be identified. Prastowo (2017) stated that the cooperation of the Directorate General of Taxes (in the future referred to as DJP) and other institutions would create a better surveillance and monitoring system to enforce the law and prevent corruption. Therefore, the effort to collect data and information from various authorities is a crucial thing that needs to be done by the DJP.

The authority in collecting data and information from external parties by the Indonesian tax authorities has been regulated in Law No. 28 of 2007 on the Third Amendment to Law No. 6 of 1983 on General Provisions and Taxation Procedures (in the future referred to as KUP Law). Article 35A of the KUP Law mentioned that every government institution, agency, association, and other parties (Instansi pemerintah, Lembaga, Asosiasi, and Pihak lain in the future referred to as ILAP), must provide data and information related to taxation to the DJP. Data and information that ILAP must provide are regulated in Article 2 paragraph (3) of Government Regulation No. 31 of 2012 concerning the Provision and Collection of Data and Information Related to Taxation. The data is grouped into 6 (six) types of data and information owned by private persons or entities related to wealth or property, debt, income earned or received, expenses incurred and/or costs, financial transactions, and economic activity.

The ILAP which is obliged to provide data and information to the DJP is regulated in Article 3 of Government Regulation (PP) Number 31 of 2012 consisting of: (1) Government institutions that include ministries, non-ministerial government agencies, agencies in the provincial government, agencies in the regency/city government and other government agencies; (2) State institutions that include State Higher Institutions, Institutions in provincial governments, institutions in regency/city governments, other government institutions and nongovernmental institutions; (3) Associations include the Chamber of Commerce and Industry (hereinafter referred to as KADIN), Association of State-Owned Banks, Association of National Commercial Banks, Indonesian Association of Public Accountants, Indonesian Employers Association (hereinafter referred to as APINDO), Indonesian Motor Vehicle Industry Association, Indonesian Young Entrepreneurs Association, Indonesian Tax Consultants Association, Indonesian Export Entrepreneurs Association and Indonesian Retail Entrepreneurs Association; and (4) Other parties stipulated through the Regulation of the Minister of Finance.

The government's commitment to collecting tax data and information is also realized through presidential instruction of the Republic of Indonesia Number 10 of 2016 on Prevention and Eradication of Corruption in 2016 and 2017. In this Presidential Instruction (in the future referred to as Inpres), one of the actions of the Tax Governance Reform Strategy and Optimization of State Revenue in the form of quality evaluation and strengthening of data exchange mechanisms and tax information from ILAP to support the achievement of tax revenue targets.

Efforts to collect tax data and information already have a solid juridical basis. However, there are still some problems in managing data and information from ILAP based on the Overview of Semester II Examination Results (in the future referred to as IHPS) in 2018, the Supreme Audit Agency (in the future referred to as BPK). The first problem, related to the development of external data from the ILAP, has not fully referred to the provisions. There is 
the potential for data set out in the Regulation of the Minister of Finance, but there is no data available in the ILAP. The second problem is related to the benchmarking of internal and external data where DJP has not thoroughly juxtaposed the internal and external data management results that have been identified and grouped with the same elements in the SPT. The third problem revealed by BPK is the optimal utilization of ILAP data and its provisions and procedures. The fourth problem is that there are no rules and standard operating procedures (SOPs) and supervision and monitoring of data development activities from ILAP (BPK, 2018:19).

In addition, the 2019 DJP Performance Report also showed there were at least three challenges in identifying priority external data. First, there is still tax-related data received from ILAP that is not fully by the data dictionary that has been established. Second, there is data that needs to be normalized first before further processing to slow down the process of processing data. Third, an ILAP still conveys hardcopy data, requiring further processing (DJP, 2019).

According to IOTA (2012), at least three factors are obstacles in managing third-party information by tax authorities, namely legal barriers, practical obstacles, and administrative burdens. The findings of the BPK examination and DJP Performance Report on the management of data and information from the ILAP above show that there are still problems at the practical level of collecting data and information related to taxation by DJP. On the other hand, tax data and information from third parties are expected to support DJP's efforts to monitor taxpayer compliance and build a tax database. For this reason, the authors are interested in conducting a review of the implementation of data collection policies and information related to taxation by the DJP. This study aims to find out how DJP carries out the collection of tax data and information. To find out the factors that influence the implementation of the policy, the authors use a hybrid model from McTigue et al. (2018).

\section{B. LITERATURE REVIEW}

According to Thomas Dye (2013:3), public policy is "what government do, why they do it, and what difference it makes". In implementing a policy, Hill and Hupe (2002:12) divide implementation analysis into four areas, namely processes, outputs, outcomes, and causal connections. According to Dunn (2008:277-278), policy input is a resource that can be in the form of time, money, personnel, tools, and materials used to produce output and impact. Policy processes are administrative, organizational, and political activities and attitudes that shape the transformation of policy input into policy output and policy outcomes. In comparison, policy output is goods, services, or resources received by the target group or beneficiaries. Lastly, policy impact is the actual change produced by policy output. A target group is an individual, community, or organization that wants to influence a policy or program. At the same time, beneficiaries are groups that receive the benefits or values of the policy.

According to Khan and Khandaker (2016), policy implementation is one of the important stages in the policy-making process, which refers to the implementation of the law, where various stakeholders and organizations work together by using procedures and techniques in carrying out policies for the achievement of goals. According to Pülzl and Treib (2007), policy implementation models can be categorized into 3 (three) models: top-down, bottom-up, and hybrid. The top-down model is often also called "policy-centred" because the focus of the researcher's attention is only on the policy and seeks to obtain the facts of whether the policy, when implemented, can achieve its goals or not (Purwanto, E.A.; Sulistyastuti, 2012:37). As for the bottom-up model, Lipsky (1971) introduced street-level bureaucracy, where discretion and policy decision greatly influence a policy's success. At the same time, the synthesis model (hybrid) seeks to overcome the gap between the top-down model and the bottom-up model by including elements from each model and other theoretical models (Pülzl, H; Treib, 2007:90). 
One method of analyzing the factors that influence policy is a hybrid model developed by McTigue et al. (2018), which studies the implementation of transportation system policies in the UK. According to McTigue et al. (2018), policy performance is influenced by the synthesis of 10 variables consisting of six variables with a top-down approach, namely (1) Policy standards and objectives; (2) Policy resources; (3) Inter-organizational communication; (4) Characteristic of implementing agencies; (5) Economic, social and political conditions; and (6) Disposition of implementers and four variables with a bottom-up approach, namely (1) Individuals at subordinate levels play an active part in implementation; (2) Policy implementation is an interactive process; (3) Policy may change during implementation; (4) Front line workers are faced with conflict and ambiguities.

A study related to the exchange of tax information has been conducted by Supriyadi (2019) in a journal entitled "Automatic Exchange of Information as a Means of Improving the Four Pillars of Compliance". This study uses a descriptive qualitative approach in automatically analyzing Automatic Exchange of Information (AEoI) data for tax purposes to improve the four pillars of tax compliance. The study found that the government has published rules related to AEoI, ranging from the law to technical instructions. However, DJP has not utilized AEoI data to improve the four pillars of tax compliance in the form of registration, reporting compliance, tax calculation and payment, and arrears payments.

The next study is in the form of a thesis conducted by Lutfia Rizkyatul Akbar (2019) with the title "Implementation of Banking Data Access Disclosure Policy in Improving Tax Compliance in Indonesia". The study analyzed how the implementation of financial information disclosure policies affected banks' reporting customer data to tax authorities with a post-positivist approach. The results showed most banks had complied in delivering banking data, but there were concerns about the confidentiality of customer data.

A study related to the exchange of financial information was conducted by Dinda Fali Rifan (2020) in a journal entitled "Analysis of the Application of Tax Transparency in the form of Financial Information Exchange". The study used a qualitative approach to analyze developmental trends in applying tax transparency in the form of financial information exchange. The results showed a trend of disclosure of tax information in the form of tax transparency. Some of the obstacles faced in disclosing information in the form of human resources, inadequate infrastructure, the absence of an audit system for the data exchanged, banking confidentiality, and protection of taxpayer rights.

Studies on the implementation of data collection policies and tax information conducted by DJP has not been widely conducted. Supriyadi (2019) only discusses how to utilize one of the external data received by DJP through AEoI. At the same time, Akbar (2019) discusses how the disclosure of banking information as one of the external data sources affects banks to report customer data for tax purposes. Rifan (2020) only focuses on the trend of the development of tax transparency in the form of financial information exchange. The study conducted by the author aims to find out the process, output, and outcomes of the policy of collecting external data and information from the ILAP and what factors affect it.

\section{METHOD}

This research uses a qualitative research approach with a post-positivist research paradigm. One of the hallmarks of the post-positivist paradigm is to use theory as a reference and central point to discover what is hidden behind the phenomena studied using data collection techniques through in-depth interviews. The reason for using the post-positivist approach in this study is that this study aims to find and understand the hidden behind the problems in implementing tax data collection policies and information in the DJP. Post-positivist research is started from theory, collecting data supporting or disproving the theory to identify and assess causes that influence outcomes (Creswell, J.W; Creswell, 2018: 41-45). 
In a qualitative approach, the research process involves questions and procedures, and researchers interpret data obtained from participants (Creswell, J.W; Creswell, 2018:41). From the aspect of the purpose of the study, this study includes descriptive research, which is a study of problems in the form of facts related to events or procedures to answer questions related to the current status of the subject studied (Digdowiseiso, 2017:31-32).

Data collection to obtain primary data through field studies by conducting in-depth interviews with sources and secondary data obtained through literature studies. The data and information collected are analyzed with interactive model data analysis techniques developed by Miles and Huberman (1994:10-12) through data reduction, presentation, conclusion withdrawal, and verification. Data triangulation compares information obtained through interviews with key informants with documents from secondary sources. The interview was conducted with several parties involved with the implementation of the policy of collecting data and tax information from DJP, namely ETS (Head of DJP External Data Management Sub-Directorate) and L (Acting Directorate of Potential Compliance and Revenue of DJP), as well as parties from outside DJP namely AP (UI Academics) and DV as tax practitioners at Danny Darussalam Tax Center (DDTC).

In this research, guidance is used to operationalize concepts consisting of variables in the form of policy implementation and variable factors that affect policy implementation. Theory from Hill and Hupe (2002) is used in the form of process, output, and outcome variables to analyze policy implementation variables. The factors that influence the implementation of the form of policy used Hybrid Theory developed by McTigue et al. (2018). Each variable is reduced to dimensions that are translated into several indicators, which are described in Table 1 .

Table 1. Concept Operationalization

\begin{tabular}{|c|c|c|}
\hline Variable & Dimension & Indicator \\
\hline \multirow{3}{*}{$\begin{array}{l}\text { Policy } \\
\text { Implementation } \\
\text { (Hill and } \\
\text { Hupe Theory, 2002) }\end{array}$} & & $\begin{array}{l}\text { - Policy formulation process } \\
\text { - Stages of policy implementation }\end{array}$ \\
\hline & Output & $\begin{array}{l}\text { - Results achieved } \\
\text { - Quality of Results } \\
\text { - Benefits received }\end{array}$ \\
\hline & Outcome & $\begin{array}{l}\text { - The impact of policies/changes resulting } \\
\text { from policy } \\
\text { - The Scale of changes made }\end{array}$ \\
\hline \multirow[t]{4}{*}{$\begin{array}{l}\text { Factors affecting } \\
\text { policy implementation } \\
\text { (Hybrid Theory } \\
\text { by Mc. Tigue, } \\
2018 \text { ) }\end{array}$} & $\begin{array}{l}\text { Policy standards and } \\
\text { objectives }\end{array}$ & $\begin{array}{l}\text { - Clarity of Purpose } \\
\text { - Strategy } \\
\text { - Conformity of policy content } \\
\text { - Policy performance targets }\end{array}$ \\
\hline & Policy resources & $\begin{array}{l}\text { - Human Resources } \\
\text { - Information System } \\
\text { - Authority } \\
\text { - Facilities }\end{array}$ \\
\hline & $\begin{array}{l}\text { Inter-organizational } \\
\text { Communication and } \\
\text { enforcement activities }\end{array}$ & $\begin{array}{l}\text { - Transmission } \\
\text { - Consistency }\end{array}$ \\
\hline & $\begin{array}{l}\text { Characteristic of implementing } \\
\text { Agencies }\end{array}$ & $\begin{array}{l}\text { - Division of tasks } \\
\text { - Availability of SOP }\end{array}$ \\
\hline
\end{tabular}




\begin{tabular}{|c|c|}
\hline $\begin{array}{l}\text { Economic, social, and political } \\
\text { Conditions }\end{array}$ & $\begin{array}{l}\text { - Form of external support } \\
\text { - Influence of external environment }\end{array}$ \\
\hline Disposition of implementers & $\begin{array}{l}\text { - Urgency of executive } \\
\text { - Response and commitment of implementers } \\
\text { - Level of supervision and control } \\
\text { - Incentives/executor awards }\end{array}$ \\
\hline $\begin{array}{l}\text { Individuals at subordinate } \\
\text { levels play an active part on } \\
\text { implementation }\end{array}$ & $\begin{array}{l}\text { - Discretion in implementation procedure } \\
\text { - Discretion on decision }\end{array}$ \\
\hline $\begin{array}{l}\text { Policy implementation is an } \\
\text { interactive process }\end{array}$ & $\begin{array}{l}\text { - Policy translation process } \\
\text { - Management of responsibilities }\end{array}$ \\
\hline $\begin{array}{l}\text { A policy may change during } \\
\text { Implementation }\end{array}$ & $\begin{array}{l}\text { - Formulation of external data policy } \\
\text { - Changes in the decision phase } \\
\text { - Changes in the implementation phase }\end{array}$ \\
\hline $\begin{array}{l}\text { Front line workers are faced } \\
\text { with conflict and ambiguities }\end{array}$ & $\begin{array}{l}\text { - Management of conflicts and ambiguities } \\
\text { - Availability of coping mechanism } \\
\text { - Availability of pattern of practice }\end{array}$ \\
\hline
\end{tabular}

Source: Reprocessed by the Authors

The use of Hybrid Theory in this study aims to find out how policies are implemented from a top-down and bottom-up perspective. In terms of top-down, this tax data collection and information collection policy is a policy that originated and was formulated by the government as a mandate of Article 35A of the KUP Law. The central government prepares rules, procedures, implementation to reporting. While from the bottom-up side, the implementation of this policy involves various actors or stakeholders who play a role in implementing the policy in the form of ILAP.

\section{RESULT AND DISCUSSION}

Based on the results of interviews and secondary data collection, the implementation of the policy of collecting data and tax information by DJP can be analyzed based on the theoretical framework of Hill and Hupe (2002) on aspects of the implementation process output and implementation impact.

\section{Policy Implementation Process}

The collection and tax information policy is carried out in several stages. First, data collection and tax information were implemented by establishing an External Data Processing Office (in the future referred to as KPDE) in 2013, responsible for formulating and conducting data searches from ILAP. Second, DJP makes guidelines for data collection and tax information activities from the formulation of data needs policy, data management to data utilization from ILAP through the issuance of SE-10 / PJ / 2015 on Guidelines for Development Administration, Utilization and Supervision of Data. In addition, DJP also formed a Tax Analysis Center Team in charge of processing, presenting, and analyzing internal and external data obtained from ILAP through the issuance of SE-62 / PJ / 2015 on the Operational Implementation of the Tax Analysis Center (Center for Tax Analysis). Third, to increase the capacity of organizations in the management of external data, the Directorate General of Taxation established the Directorate of Tax Data and Information (DIP) in 2019. With the establishment of the Directorate of Tax Data and Information (DIP), KPDE was liquidated. The establishment of the DIP Directorate as a special unit that focuses on managing tax data is a step forward in the governance of tax data. 
The practice of collecting third-party data is also a concern for tax authorities in many countries. It is reinforced by the OECD report (2019) that there is an increase in the availability of data from third parties in various countries regarding the storage, transfer, and integration done electronically through new applications, processes, and techniques for tax compliance purposes. The OECD (2017) recommends that the ideal form of reporting and information sharing mechanisms is well-managed mandatory.

According to the OECD (2019), most third-party data received comes from other government agencies. The policy of collecting data and information from ILAP becomes one of the data sources to build big data on the Indonesian tax system. According to van der Enden and Roytman (2015), Big Data can help tax authorities test and understand taxpayers' history of activities and behaviours. Efforts to collect tax data and information by DJP are expected to be the foundation of Big Data taxation in Indonesia.

\section{Policy Implementation Output}

Aspects of policy output are analyzed from the amount of data obtained and identified and the quality of the data received. The achievement of the amount of ILAP data identified by DJP compared to the amount of data received in the period 2017 - 2019 shows an increasing trend. The realization of priority data was identified in 2017 by $63.55 \%$ and increased in 2019 to $68.85 \%$. The number of prioritized ILAP identified by the Directorate General of Taxes from 2017-2019 amounted to 156,209,568, 274,435,909, 72,987,953, respectively. The number of Priority ILAP in 2017 amounted to 36 ILAP, in 2018 amounted to 41 ILAP, and in 2019 as many as 36 ILAP. The development of the number of ILAP and Priority Data Identified in 2017-2019 can be seen in Table 2 below:

Table 2. Development of ILAP Data Identification Period 2017 - 2019

\begin{tabular}{ccccc}
\hline Year & $\begin{array}{c}\text { Number of } \\
\text { Prioritized ILAP }\end{array}$ & $\begin{array}{c}\text { Amount of Priority } \\
\text { Data Received }\end{array}$ & $\begin{array}{c}\text { Amount of Identified } \\
\text { Priority Data }\end{array}$ & $\begin{array}{c}\text { Identification } \\
\text { Achievements }\end{array}$ \\
\hline 2017 & 36 ILAP & $245,816,632$ & $156,209,568$ & $63.55 \%$ \\
2018 & 41 ILAP & $422,720,676$ & $274,435,909$ & $64.92 \%$ \\
2019 & 36 ILAP & $106,013,601$ & $72,987,953$ & $68.85 \%$ \\
\hline
\end{tabular}

Source: DJP Performance Report 2019, reprocessed by Authors

The data quality received by DJP from ILAP can be reviewed from the variables of completeness, validity, and conformity. Quality is a situation where inherent characteristics consistently meet the organization's customers and other stakeholders (Elshaer, 2012). Based on the evaluation conducted by the Directorate General of Taxes accumulatively from 2013 to 2019 , the aspect of completeness is $30 \%$, the validity aspect is $60 \%$, and the conformity aspect is $70 \%$. The completeness of data from ILAP received by DJP is still low compared to conformity and validity aspects. This can be seen in Table 3:

Table 3. Quality of ILAP Data Received

\begin{tabular}{llrl}
\hline No Quality Measure & Percentage & \multicolumn{1}{c}{ Remark } \\
\hline 1 & Completeness & $30 \%$ & Conformity of ILAP data submitted with PMK \\
2 & Validity & $60 \%$ & $\begin{array}{l}\text { Conformity of ILAP data to NPWP (Tax } \\
\text { Payer's Identification Number) and NIK } \\
\text { (Citizenship Identification Number) data on }\end{array}$ \\
& & $\begin{array}{l}\text { DJP master files } \\
\text { Conformity of ILAP data content with the } \\
\text { format in the data dictionary }\end{array}$ \\
\hline
\end{tabular}

Source: 2019 DJP reprocessed by Authors 
The data that has been identified will be stored in the data warehouse for further use in taxpayer supervision. Data that has gone through identification with a certain Level of Confidence will produce data with which it is connected to Citizenship Identification Number (in the future referred to as NIK) and Tax Payer's Identification Number (in the future referred to as NPWP) based on the database owned by DJP. The tax officer will use data that NIK and NPWP have completed for tax intensification by analyzing the data submitted in the Taxpayer Tax Return. As for the data that only identified the NIK is carried out the tax expansion process. However, the DJP information system does not provide a special notification feature for ILAP data. In addition, DJP does not yet have a reporting mechanism for data from ILAP.

\section{Impact of Policy Implementation}

The impacts of implementation of data and information collection policy from ILAP is how that policy impacts tax revenue performance and taxpayer compliance. DJP does not yet have the tools to measure the extent of the impact of policy implementation on tax revenue and taxpayer compliance. According to one of the sources from DDTC initials DV, ILAP data is only one of several factors that affect tax revenue. How data governance ranges from data receipts to generating information that can be further utilized also determines the effect of policy on tax revenues. Therefore, the impact of policy requires further analysis. According to Wicaksono and Musri (2019), with better surveillance methods, taxpayers are expected to have the intention to be more compliant because the possibility of detection is getting higher.

DJP is building a Compliance Risk Management (CRM) system in decision-making tools in DJP and Core Tax System business processes to replace the current tax information system. Compliance Risk Management (CRM) is a systematic process through identification, analysis, assessment, prioritization, handling, and evaluation of the risk of taxpayer non-compliance with their tax obligations to help tax authorities improve compliance. It aligns with Pratomo's research (2018) which emphasizes the urgency of using Compliance Risk Management (CRM) as tax compliance governance. With the availability of ILAP data on the DJP database, resource investment is needed to construct an integrated database. Therefore, the momentum of CRM and Core Tax System development by DJP is currently expected to accommodate the needs of an integrated tax data system. The same is conveyed by DV sources from DDTC as follows:

"The data is currently available, but how the data processing can be effective. CRM will certainly need technology and technology investment. Currently, the government prepares a Core Tax to support data from ILAP or the core system of tax administration (SIAP). The goal is to ensure the data processing and information received by DJP". (interview, November 12, 2019).

According to Gunadi (2016), implementing the self-assessment system aims to improve taxpayer compliance, accelerate the tax determination process, reduce compliance and administrative costs, and accelerate tax collection. One of the factors that influence the behaviour of taxpayers to minimize their tax obligations both legally and illegally, according to Santoso and Rahayu (2013), is the risk of detection from tax authorities. On the other hand, taxpayers will also always look for loopholes to commit tax non-compliance. Therefore, according to Irawan \& Budiono (2015), data plays a role in selecting taxpayers who will be examined and finding out how much tax gap the taxpayer has. Langham et al. (2012) stated that one of the efforts to address tax non-compliance is that tax authorities must understand the weaknesses of system design and try to apply system improvements. Through the construction of CRM and the Core Tax System, it is expected that DJP's efforts to improve taxpayers' supervision system can be realized. 


\section{Factors That Affect the Implementation of Tax Data collection and Information Policy}

Based on in-depth interviews that the authors conducted with informants on ten factors that influence policy implementation according to McTigue et al. (2018), the authors took 3 (three) of the most dominant factors as implementation inhibitors and 3 (three) of the most prevalent factors as support for implementation. Each factor that affects the implementation of the policy is given a score with a maximum score of 3 points while the minimum score is 1 point.

From the highest scoring results, it is obtained 3 (three) factors that hinder the implementation of policies in the form of policy standards and objectives, policy resources and inter-organizational communication and enforcement activities. The factors that support the implementation of policies in the form of disposition of implementers, individuals at subordinate levels, and Front-line workers are faced with conflict and ambiguities, as can be seen in Table 4 below:

Table 4. Score of Factors Affecting Policy Implementation

\begin{tabular}{llcc}
\hline No & \multicolumn{1}{c}{ Factor } & Inhibition & Support \\
\hline 1 & Policy standards dan objectives & 3 & 1 \\
2 & Policy resources & 3 & 1 \\
3 & Inter-organizational communication and enforcement & 3 & 1 \\
4 & Characteristics of implementing agencies & 1 & 2 \\
5 & Economic, social dan political conditions & 1 & 2 \\
6 & Disposition of implementers & 1 & 3 \\
7 & Individuals at subordinate levels & 1 & 3 \\
8 & Policy implementation is an interactive process & 1 & 2 \\
9 & The policy may change during implementation & 1 & 2 \\
10 & Front line workers are faced with conflict and & 1 & 3 \\
& ambiguities & & \\
\hline
\end{tabular}

Source: Processed by Authors

\section{Implementation Inhibiting Factors}

Policy Standards and Objectives

The purpose of collecting tax data and information from ILAP is to carry out the mandate of Article 35A of the KUP Act to form a tax database, and support taxpayer compliance supervision efforts, and create a taxpayer profile. As stated by source L (Lembaga/Agency) from the PKP Directorate, the purpose of collecting tax data and information is to test taxpayer compliance with comparison data from credible third parties, one of which comes from ILAP.

The same thing was revealed by DV sources from DDTC, who revealed that the collection of ILAP data can be a means to achieve the accuracy of examination and increase audit coverage ratio (ACR) in Indonesia, which is currently still below 3\%. The inspection can be started by targeting taxpayers with income profiles that do not match the external data received by the DJP from ILAP. AP sources as UI academics also emphasized the importance of thirdparty data to be reconstructed to create a taxpayer profile after validation and become concrete data to be juxtaposed with the tax return from the taxpayer.

However, at the beginning of the formation of KPDE as a unit explicitly formed to collect data and information from ILAP, it does not have guidance on the direction of the data needs policy. KPDE is only responsible for formulating and searching for data, but the data obtained has not been the focus. This was revealed by the Head of the Regional Directorate of External Data Management (PDE) DJP initials ETS that stated that this policy target initially only refers 
to the amount of ILAP data received and identified as stated in the DJP Performance Report in 2018. The target for the use and use of ILAP data has not yet been determined. It has not been established and accompanied by evaluation and monitoring of the amount of data that has or has not been utilized. It is the cause of the hampered implementation of tax data collection and information policy to achieve policy objectives since the establishment of KPDE in 2013 until mid-2019 before establishing the Directorate of Tax Data and Information as of the implementer of the policy.

\section{Policy Resources}

Resources in implementing data and information collection policies related to taxation from ILAP consist of human resources (HR), budget, and availability of information technology. From the HR aspect, most employees have a Diploma I and Diploma III in Finance from STAN. The number of available personnel is still limited based on workload analysis conducted internally to collect data from ILAP because not all ILAP has provided data in electronic form. There is still a lot of data that has not been digitized, so it requires data scanning.

From the information technology aspect, software under Pentaho is available to match data from ILAP with internal databases owned by DJP. The budget for the provision of information technology has not been available every year since the first procurement in 2015. The DJP processing unit develops an independent monitoring system under DIAMOND (Digitization of Administrative Information and Data Monitoring) for supervision and performance monitoring. This system functions as a monitoring tool of each ILAP data handler to display the ILAP data flow since the data is received, processed and then forwarded to the next unit. In addition, control over the amount of data received, the person in charge of each, and how long the data is processed can be known. However, no information system can control and supervise the supervision of the amount of data that has been or has not been utilized, how the utilization of data by data users, and the extent to which the data can be helpful for tax revenue.

\section{Inter-organizational Communication and Enforcement Activities}

Some communication problems occur when ILAP data management is still carried out by KPDE and the Directorate of Taxation Technology and Information (TIP). The initiative carried out by KPDE by providing identity to data from ILAP that is not regulated by the provisions in SE-10 / PJ / 2015 is not well communicated with the TIP Directorate as the unit that presents data from ILAP to data users. As a result of these communication barriers, when data is sent to the TIP Directorate, the column containing the identity of the data is not used. It causes the data to be recorded, so the data usage control cannot be carried out.

The following communication obstacle is the communication constraint between KPDE as an ILAP data management unit at the central level and a vertical unit at the DJP Regional Office level. Under the provisions of SE-10 / PJ / 2015, the DJP Regional Office is also responsible for ensuring the completeness of the data and clarifying when obtaining data and information from local governments that do not provide data under the provisions. However, not all DJP regional offices know the task and carry out the follow-up as it should.

\section{Supporting Factors for Implementation}

\section{Disposition of Implementers}

The motivation of policy implementers to enable data and information from ILAP is quite high. The establishment of the Directorate of Taxation Data and Information responsible for the management of data from ILAP brought the consequences of the dissolution of the previously responsible unit, the External Data Processing Office (KPDE). This change opens up opportunities for the improved work ethic of policy implementers. It is due to the reward in 
the form of increased remuneration obtained by employees compared to when still at KPDE. In addition, the role of the administrative officer to implement policies on the importance of managing data from ILAP for the benefit of state revenue also becomes a factor that increases the motivation of implementers. Policy implementers also understand that the consequence of such responsibilities and demands is improving performance carried out to achieve policy objectives.

According to Kadji (2015:64), the tendency of the implementer's attitude is defined as the desire and approval to implement the policy. Policy implementers must know and implement the policy and have the desire and motivation to implement the policy. Subarsono (2005:9192) emphasizes that disposition is the character and characteristics possessed by implementors, such as commitment, honesty, democratic nature, etc. When implementors have different attitudes or perspectives with policymakers, the policy implementation process becomes ineffective.

\section{Individuals at Subordinate Levels}

One form of the active role of implementing policies at the lower level is innovation when facing conditions in the form of low levels of completeness of ILAP data received. When referring to the provisions of the details of the type of data that must be provided, the data is not considered complete before fulfilling the details, time of submission, and form of data. So that the data received is optimal and not counterproductive, which results in delays in receiving data, it is necessary to set mandatory fields for ILAP data by involving the role of data users. So that the ILAP data can still be accepted even though it is incomplete as long as it fulfils the mandatory field.

In addition, although the KUP Act legally supports the implementation of this policy and there is a sanction for those who do not comply, in reality, technical instructions for the implementation of sanctions are not yet available. The problem that arises is that each ILAP has its characteristics and uniqueness depending on the bureaucratic structure and policy of the ILAP organization. Therefore, the policy implementers at DJP made a breakthrough to exchange information between DJP and ILAP institutions in the form of a Cooperation Agreement (in the future referred to as PKS) that contained the rights and obligations of both parties.

According to Bertot et al. (2016), innovation in the public service sector is a change that produces something new by creating new ideas, practices, new technologies, and forms of service by creating new values. Innovation in a cooperation agreement between DJP and ILAP becomes an alternative solution to overcome ILAP non-compliance. The form of mutual understanding or Cooperation Agreement (PKS) developed into a joint analysis between DJP and ILAP. The Cooperation Agreement and Joint Analysis were not formulated earlier in PP (Government Regulation) Number 31 of 2012 and PMK Number 228/PMK.03 of 2017 and SE-10/PJ/2015. But the barriers faced in achieving policy objectives result in innovation and simplification to the implementation of data collection policies from ILAP.

\section{Front Line Workers are Faced with Conflict and Ambiguities}

The establishing the Directorate of Taxation Data and Information does not automatically overcome all obstacles previously faced by KPDE in collecting and managing data from ILAP. Adaptation to the lack of resources in implementing policies is carried out by forming 3 (three) coordinators who oversee each person in charge of data. Limited resources in information technology support also trigger creativity and innovation from policy implementers. The limitations of the information system provided by DJP for supervision of data management from ILAP trigger KPDE to develop DIAMOND applications independently. 
The implementation of collecting data and information related to taxation from ILAP has adapted to the conflicts and ambiguities of the policy. In policy implementation, implementers can face some conflicts and ambiguities. To face these problems, lower-level bureaucrats or street-level bureaucrats often seek solutions with coping mechanisms and patterns of practice to narrow the gap between policy objectives and existing resources (Lipsky, 1971). According to Mahsyar (2013), forms of coping behaviours carried out by street-level bureaucrats arise due to limited organizational resources.

\section{E. CONCLUSION}

Based on the discussion above, it can be known that the policy of collecting tax data and information on the DJP aims to build a tax database and form a taxpayer profile. One of the efforts to succeed in this policy objective is to change the DGT's organizational structure by establishing the Directorate of Tax Data and Information. However, the implementation of this policy is not optimum. It is due to the limitations of information systems that caused by the absence of data usage monitoring tools and data identity. In addition, the level of completeness of data from the ILAP is low due to the lack of implementation rules in the application of sanctions against ILAP non-compliance.

There are several factors that inhibit this policy's implementation. First, the setting of policy objectives and standards has not been established with focus and measurable, especially related to monitoring data utilization. Second, there are no available resources in tools for monitoring data use. Third, communication and coordination between policy implementing units have not been optimal. The factors that support the implementation of policies are the motivation of high policy implementers, the active role of policy implementers in finding alternative solutions to ILAP non-compliance, and the ability of implementors to adapt and innovate with the limited resources available.

Some suggestions that DJP can make are first, issuing implementation rules concerning applying sanctions to ILAP that do not meet the obligation to provide data and information to DJP. This aims to improve ILAP compliance and facilitate enforcement carried out by DJP. Furthermore, DJP needs to improve its procedures and governance of data and information through the revision of SE-10/PJ/2015. Its contents regulate the obligation to provide monitoring tools for data use that can be carried out in real-time and require the use of data identified from the time the ILAP data is received until data users utilize it. This aims at ensuring supervision and reporting of ILAP data utilization can be more optimum. Finally, the Directorate General of Taxes needs to consider rewarding compliant ILAP through special incentives and rewards. It aims to improve ILAP motivation and compliance in providing data to DJP.

\section{REFERENCES}

Akbar, L. R. (2019). Implementasi Kebijakan Keterbukaan Akses Data Perbankan Dalam Meningkatkan Tax Compliance di Indonesia. Universitas Indonesia.

Bertot, John; Estevez, Elsa; Janowski, T. (2016). Universal and Contextualized Public Services: Digital Public Service Innovation Framework. Government Information Quarterly, 33(2), 211-222.

BPK. (2018). Ikhtisar Hasil Pemeriksaan Semester II.

Creswell, J.W.; Creswell, J. D. (2018). Research Design: Qualitative, Quantitative, and Mixed Methods Approaches (Fifth). SAGE Publications Incorporations.

Digdowiseiso, K. (2017). Metodologi Penelitian Ekonomi dan Bisnis (Suharyono (ed.); Edisi Pert). Lembaga Penerbitan Universitas Nasional.

DJP. (2019). Laporan Kinerja DJP.

Dunn, W. N. (2008). Public Policy Analysis: An Introduction (Fourth). Pearson : Prentice Hall. 
Dye, T. R. (2013). Understanding Public Policy (14th Ed (ed.)). Pearson.

Elshaer, I. (2012). What is the Meaning of Quality. MPRA, 57345. https://mpra.ub.unimuenchen.de/id/eprint/57345

Gunadi, G. (2016). Panduan Komprehensif Ketentuan Umum Perpajakan (KUP) (Revisi). Bee Media Indonesia.

Hill, Michael; Hupe, P. (2002). Implementing Public Policy (First). Thousand Oaks. Sage Publications. Inc.

IOTA. (2012). IOTA Report for Tax Administration: Third party information. www.iotatax.org

Irawan, Bambang; Budiono, T. (2015). Analisis Pemeriksaan Pajak Dalam Rangka Optimalisasi Penerimaan Negara di Sektor Perpajakan. Transparansi, VII(2), 142-155.

Kadji, Y. (2015). Formulasi dan Implementasi Kebijakan Publik: Kepeminpinan dan Perilaku Birokrasi dalam Fakta Realitas (Pertama). Universitas Negeri Gorontalo Press.

Khan, A. R., \& Khandaker, S. (2016). A Critical Insight into Policy Implementation and Implementation Performance. 15(4), 538-548. https://doi.org/10.13165/VPA-16-15-4-02

Langham, Jo' Anne; Paulsen, Neil; Härtel, C. E. J. (2012). Improving Tax Compliance Strategies: Can the Theory of Planned Behavior Predict Business Compliance? E-Journal of Tax Research, 10(2).

Lipsky, M. (1971). Street level bureaucracy and the analysis of urban reform. Urban Affairs Quarterly, 6, 391-409.

Mahsyar, A. (2013). Coping Behaviors oleh Street-Level Bureaucrats Dalam Pelayanan Kesehatan di Kota Makassar. Universitas Hasanuddin.

Mctigue, C., Rye, T., \& Monios, J. (2018). Case Studies on Transport Policy The role of reporting mechanisms in transport policy implementation by local authorities in England. Case Studies on Transport Policy, 6(3), 319-328. https://doi.org/10.1016/j.cstp.2017.12.002

Miles, Matthew, B.; Huberman, M. A. (1994). Qualitative Data Analysis : A Sourcebook of New Method (2nd Editio). SAGE Publications Incorporations.

Nugroho, M. T. (2018). Kepatuhan Wajib Pajak vs Pemeriksaan Pajak: Quo Vadis? Www.Acurat.Co. https://akurat.co/kepatuhan-wajib-pajak-vs-pemeriksaan-pajak-quovadis

OECD. (2017). Effective Inter-Agency Co-operation in Fighting Tax Crimes and Other Financial Crimes (Third). OECD Publishing.

OECD. (2019). Tax Administration 2019: Comparative Information on OECD and other Advanced and Emerging Economies. OECD Publishing. https://doi.org/https://doi.org/10.1787/74d162b6-en

Prastowo, Y. (2017). New Perspective of Comprehensive Reform: Integrating Corruption Eradication and Tax Optimization Agenda. Paper Presented at Tax and Corruption Symposium.

Pratomo, M. H. (2018). Investigating Tax Compliance Risks of Large Business in Indonesia. RMIT University.

Pülzl, H; Treib, O. (2007). Implementing Public Policy. In M. S. Fischer, Frank; Miller, G.J.; Sidney (Ed.), Handbook of Public Policy Analysis : Theory, Politics, and Methods. . Boca Raton : CRC Press-Taylor Francis Group.

Purwanto, E.A.; Sulistyastuti, D. R. (2012). Implementasi Kebijakan Publik: Konsep dan Aplikasinya di Indonesia. Gava Media.

Rifan, D. F. (2020). Analisis Penerapan Transparansi Perpajakan Berupa Pertukaran Informasi Keuangan. Jurnal Akuntansi Aktual, 7(1), 23-30. https://doi.org/http://dx.doi.org/10.17977/um004v7i12020p23

Santoso, Iman; Rahayu, N. (2013). Corporate Tax Management: Mengulas Upaya 
Pengelolaan Pajak Perusahaan Secara Konseptual-Praktikal. Ortax.

Simanjuntak, J. (2017). Indonesia Masuk Peringkat ke-11 Penghindaran Pajak Perusahaan, Jepang No.3. Www. Tribunnews.Com. https://www.tribunnews.com/ internasional /2017/ 11/20/indonesia-masuk-peringkat-ke-11-penghindaran-pajak-perusahaan-jepang-no3

Subarsono, A. (2005). Analisis Kebijakan Publik: Konsep, Teori dan Aplikasi. Pustaka Pelajar. Supriyadi, S. (2019). Automatic Exchange of Information sebagai Sarana Meningkatkan Empat Pilar Kepatuhan Pajak. Jurnal Reformasi Administrasi, 6(2), 114-123. https://doi.org/https://doi.org/10.31334/reformasi.v6i2.525

van der Enden, Eelco; Roytman, M. (2015). Technology and Tax Compliance. How Technology is shaping the Tax Administration of the Future. 2015 FTA Project Workshop, Vertex, $P w C$.

Wicaksono, R., \& Musri, B. (2019). Alternatif Desain Pengawasan dan Penghitungan Pajak Penghasilan Orang Pribadi Berdasarkan Harta Bersih. Jurnal Pendidikan Akuntansi Dan Keuangan, 7(2), 111-126. https://doi.org/10.17509/jpak.v7i2.17129 